\title{
Syphilis mimicking trigeminal schwannoma
}

\section{Sífilis imitando schwannoma trigeminal}

\author{
Gustavo L. F. Honorio', Samila O. Silva', Marcos M. Silva', Marco A. Lima'
}

A 20-year-old woman presented with a two-month history of temporal headache and right trigeminal nerve palsy. An MRI showed enlargement and contrast enhancement of the right trigeminal nerve, suggestive of a schwannoma (Figure A). Cerebrospinal fluid analysis disclosed: 10 cells $/ \mathrm{mm}^{3}$, protein $76 \mathrm{mg} / \mathrm{dl}$, glucose $50 \mathrm{mg} / \mathrm{dl}$ and positive Venereal Disease Research Laboratory test (VDRL).
Serum VDRL was $1 / 256$ and the Treponema pallidum haemagglutination was positive. She was treated with IV crystalline penicillin G 2.400.000 U/day for 14 days with clinical and radiological improvement (Figure B).

Gummatous cranial nerve palsy is rarely reported ${ }^{1,2}$ as the sole manifestation of syphilis, but should be considered in the differential diagnosis of nerve tumors.
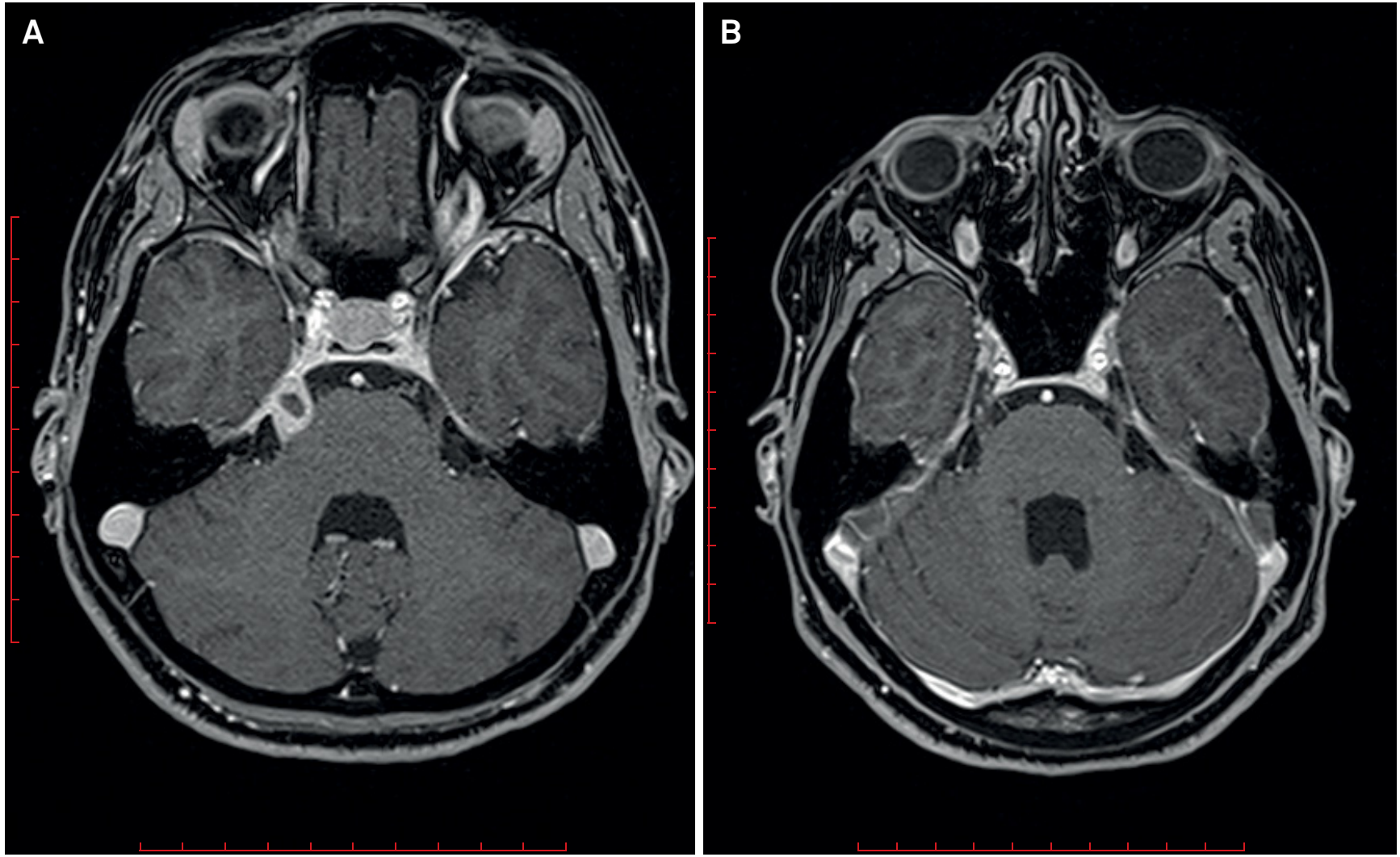

Figure. Axial T1-weighted brain MRI showing enlargement and contrast enhancement in the right trigeminal nerve (A) and resolution after treatment with crystalline penicillin $G(B)$

1. Seeley WW, Venna N. Neurosyphilis presenting with gummatous oculomotor nerve palsy. J Neurol Neurosurg Psychiatry. 2004;75(5):789. http://doi.org/10.1136/jnnp.2003.025932
2. Hess CW, Rosenfeld SS, Resor SR. Oculomotor nerve palsy as the presenting symptom of gummatous neurosyphilis and human immunodeficiency virus infection: clinical response to treatment.JAMA Neurol. 2013;70(12):1582-3.http://doi.org/10.1001/jamaneurol.2013.1485

${ }^{1}$ Universidade Federal do Rio de Janeiro, Hospital Universitário Clementino Fraga Filho, Serviço de Neurologia, Rio de Janeiro RJ, Brasil. Correspondence: Marco A. Lima; Avenida Alexandre Ferreira, 420 / apt 403; 22470-220 Rio de Janeiro RJ, Brasil; E-mail: masdlima@gmail.com Conflict of interest: There is no conflict of interest to declare.

Received 12 July 2016; Accepted 13 September 2016. 